\title{
INFLUENCE OF AGE AND GENDER ON THE PHARMACODYNAMIC PARAMETERS OF ROCURONIUM DURING TOTAL INTRAVENOUS ANESTHESIA
}

\author{
Milan Adamus $^{\mathrm{a} *}$, Lumir Hrabalek ${ }^{\mathrm{b}}$, Tomas Wanek ${ }^{\mathrm{b}}$, Tomas Gabrhelik ${ }^{\mathrm{a}}$, Jana Zapletalova ${ }^{\mathrm{c}, \mathrm{d}}$ \\ ${ }^{a}$ Department of Anesthesiology and Intensive Care Medicine, University Hospital Olomouc and Faculty of Medicine and \\ Dentistry, Palacky University Olomouc, Czech Republic \\ ${ }^{b}$ Department of Neurosurgery, University Hospital Olomouc and Faculty of Medicine and Dentistry, Palacky University \\ Olomouc \\ c Department of Medical Biophysics, Faculty of Medicine and Dentistry, Palacky University Olomouc \\ ${ }^{d}$ Institute of Molecular and Translational Medicine, Faculty of Medicine and Dentistry, Palacky University Olomouc \\ E-mail: milan.adamus@seznam.cz
}

Received: June 28, 2011; Accepted: September 21, 2011; Available online: November 1, 2011

Key words: Rocuronium/Neuromuscular Blockade/Age/Gender

\begin{abstract}
Aims. To compare the pharmacodynamics of $0.6 \mathrm{mg} \mathrm{kg}^{-1}$ rocuronium in young and older patients of both genders during total intravenous anesthesia.

Methods. Following local ethics committee approval and informed consent, patients scheduled for surgery under total intravenous anesthesia (propofol/sufentanil) were divided into 4 study groups: 37 males aged 20-40, 40 males aged 60-75 yrs, 43 females aged 20-40 and 38 females aged 60-75 yrs. Neuromuscular block following rocuronium $\left(0.6 \mathrm{mg} \mathrm{kg}^{-1}\right)$ was monitored: train-of-four [TOF] stimulation of the ulnar nerve at 15-s intervals, EMG of the adductor pollicis muscle. The onset time (from application of rocuronium to maximum depression of $\mathrm{T}_{1}$ ), clinical duration (from application to $25 \%$ recovery of $\mathrm{T}_{1}$ ), and time to full spontaneous recovery (from application to TOF-ratio $\geq 0.9$ ) were determined for each patient. The Kruskal-Wallis test was used to compare differences between groups; $P<0.05$ was considered statistically significant.

Results. The onset time (median [interquartile range]) in the respective groups was 90 [80-110 $]^{\mathrm{BCD}}, 135[116-165]^{\mathrm{AC}}$, $75[60-90]^{\mathrm{ABD}}$, and $120[90-146]^{\mathrm{AC}}$ seconds. The clinical duration was 30 [25-42 $^{\mathrm{BCD}}, 58[53-67]^{\mathrm{AD}}, 50[40-65]^{\mathrm{AD}}$, and $85[70-90]^{\mathrm{ABC}}$ min. Interval to full spontaneous recovery was $59[51-67]^{\mathrm{BCD}}, 102[75-106]^{\mathrm{A}}, 76[66-91]^{\mathrm{AD}}$, and $128[94-$ $137]^{\mathrm{AC}}$ min. ( ${ }^{\mathrm{A} P} P<0.05$ vs. young males, ${ }^{\mathrm{B}} P<0.05$ vs. elderly males, ${ }^{\mathrm{C}} P<0.05$ vs. young females, ${ }^{\mathrm{D}} P<0.05$ vs. elderly females).

Conclusion. Females and older patients were more sensitive to rocuronium.
\end{abstract}

\section{INTRODUCTION}

Rocuronium (ROC) is a modern aminosteroidal neuromuscular blocking agent (NMBA) with intermediate clinical duration of action (30-50 $\mathrm{min})$. Introduced into clinical practice in 1994 (ref. ${ }^{1}$ ), it is now frequently used during general anesthesia worldwide. Of the non-depolarizing NMBAs, ROC has the fastest onset (45-60 s), and to facilitate tracheal intubation in elective cases, it is gradually replacing suxamethonium ${ }^{2,3}$.

The drug dose is usually calculated according to patient body weight. However, the effect of a number of anesthetic agents, including aminosteroidal NMBAs, can be influenced by a large number of other factors including gender ${ }^{4,5}$ and age $e^{6-8}$.

The aim of this study was to compare the pharmacodynamics (PD) of the rocuronium, following a single dose $\left(0.6 \mathrm{~m} \mathrm{~kg} \mathrm{k}^{-1}\right)$ in young and older males and females during total intravenous anesthesia (TIVA).

\section{MATERIALS AND METHODS}

This was a prospective, non-interventional, non-blinded, clinical study. Its protocol did not alter the routine anesthetic care at the main author's department.

After obtaining the Hospital Ethics Committee approval and written informed consent to anesthesia, adult patients, scheduled for elective surgery under total intravenous anesthesia with tracheal intubation, muscle relaxation with single bolus dose of rocuronium and mechanical ventilation, were enrolled. The expected duration of surgery was about 60-120 min. The management of anesthesia was identical in all patients but only males and females of two age groups (20-40 and 60-75) were studied.

Exclusion criteria were ASA physical status more than 3 , obesity (BMI more than $30 \mathrm{~kg} \mathrm{~m}^{-2}$ ), anticipated difficult tracheal intubation, age outside the selected range. Patients using medication known to interfere with NMBA and those with severe renal, hepatic, metabolic, or neuromuscular diseases were not studied either. Patients in whom the initial dose of rocuronium had to be supplemented with one or several top-ups, or those in whom the reversal was administered, were also excluded. Unstable 
neuromuscular blockade (NMB) monitoring was also a reason for exclusion.

A pre-anesthetic questionnaire was used to collect patients' demographic data (gender, age, weight, height, ASA physical status classification) and BMI (body mass index) was computed.

\section{Anesthesia}

We used standardized anesthetic techniques in all patients ${ }^{5}$. The patients were premedicated orally with diazepam 5-10 mg $1 \mathrm{~h}$ before the beginning of surgery. On arrival in the operating room, an intravenous cannula was inserted into a vein of the forearm contralateral to NMT (neuromuscular transmission) measurement. After 3-min preoxygenation, midazolam (1-3 $\mathrm{mg})$ and sufentanil (0.1 $\mu \mathrm{g} \mathrm{kg}{ }^{-1}$ ) were injected intravenously. Total intravenous anesthesia in TCI mode (target-controlled infusion) was induced and maintained with a Base Primea ${ }^{\circledR}$ (Fresenius Vial) infusion device. Target plasmatic concentration was initially set to $2.0 \mu \mathrm{g} \mathrm{ml}^{-1}$ for propofol in Schnider's model $^{9,10}$ and $1.8 \mathrm{ng} \mathrm{ml}^{-1}$ for sufentanil in Gepts's model ${ }^{9,11}$, respectively, and adjusted according to blood pressure and heart rate during anesthesia. To facilitate tracheal intubation, neuromuscular block was induced with a single bolus dose of rocuronium $\left(0.6 \mathrm{mg} \mathrm{kg}^{-1}\right)$ injected intravenously over 5 seconds. Following maximal depression of $\mathrm{T}_{1}$ (onset time), tracheal intubation was performed. The endotracheal tube was connected to "low-flow" anesthetic breathing circuit with a mixture of $40 \%$ oxygen in air; mechanical ventilation was adjusted to maintain endtidal partial pressure of carbon dioxide $\left(\mathrm{E}_{T} \mathrm{CO}_{2}\right)$ between 4.7 and $5.0 \mathrm{kPa}$. When necessary, supplemental top-ups of $5 \mathrm{mg}$ rocuronium were administered. Sufentanil and propofol were discontinued 10 minutes before the end of anesthesia and extubation was not performed before full recovery from neuromuscular block (TOF-ratio $\geq$ $0.90)$. When required, the recovery was accelerated with neostigmine $\left(0.04 \mathrm{mg} \mathrm{kg}^{-1}\right)$ given together with atropine $\left(0.015 \mathrm{mg} \mathrm{kg}^{-1}\right)$.

\section{Neuromuscular block and monitoring}

This study was conducted in accordance with good clinical research practice in pharmacodynamic studies of neuromuscular blocking agents ${ }^{12}$. We used the NMT module of the AS/3 $3^{\mathrm{TM}}$ Anaesthesia Monitor (Datex-Ohmeda) and the monitoring system was connected to the patient before induction of anesthesia. Following careful skin preparation of the right distal forearm, five skin electromyographic monitoring electrodes (H124, Kendall) were applied over the ulnar nerve and adductor pollicis muscle as appropriate. The forearm was immobilized in supination on a splint. Skin temperature was monitored using a probe placed on the dorsum of the hand from which the response to ulnar nerve stimulation was recorded. The temperature was maintained above $34{ }^{\circ} \mathrm{C}$ throughout the study period by wrapping the arm in cotton wool. After anesthesia induction, but before administration of rocuronium, the NMT monitor was calibrated using the automatic start-up-procedure. For measurements, we used TOF (train-of-four) assessed at 15-s intervals by stimulation of ulnar nerve with four rectangular impulses at $2 \mathrm{~Hz}$, duration $0.2 \mathrm{~ms}$ and supramaximal current. The evoked electromyographic response of adductor pollicis muscle was monitored. The height of twitch response to first im-

Table 1. Patients' demographic data.

\begin{tabular}{|c|c|c|c|c|c|}
\hline & \multicolumn{2}{|c|}{ Males (M) } & \multicolumn{2}{|c|}{ Females $(F)$} & \multirow[b]{2}{*}{$P$-value } \\
\hline & $\begin{array}{c}\text { Young } \\
(20-40 \mathrm{yr})\end{array}$ & $\begin{array}{c}\text { Elderly } \\
(60-75 \mathrm{yr})\end{array}$ & $\begin{array}{c}\text { Young } \\
(20-40 \mathrm{yr})\end{array}$ & $\begin{array}{c}\text { Elderly } \\
(60-75 \text { yr })\end{array}$ & \\
\hline No & 37 & 40 & 43 & 38 & $0.633^{\mathrm{a}}$ \\
\hline Age (yr) & $\begin{array}{l}31 \pm 7^{\mathrm{BD}} \\
(29-33)\end{array}$ & $\begin{array}{l}66 \pm 4^{\mathrm{AC}} \\
(65-67)\end{array}$ & $\begin{array}{l}29 \pm 6^{\mathrm{BD}} \\
(28-31)\end{array}$ & $\begin{array}{l}67 \pm 4^{\mathrm{AC}} \\
(66-68)\end{array}$ & $<0.0001^{\mathrm{b}}$ \\
\hline Weight (kg) & $\begin{array}{l}74 \pm 9^{\mathrm{D}} \\
(71-77)\end{array}$ & $\begin{array}{l}76 \pm 9^{C D} \\
(74-79)\end{array}$ & $\begin{array}{l}68 \pm 11^{\mathrm{B}} \\
(65-72)\end{array}$ & $\begin{array}{c}66 \pm 11^{\mathrm{AB}} \\
(63-70)\end{array}$ & $<0.0001^{\mathrm{b}}$ \\
\hline Height $(\mathrm{cm})$ & $\begin{array}{c}171 \pm 9^{\mathrm{CD}} \\
(168-173)\end{array}$ & $\begin{array}{c}174 \pm 7^{\mathrm{CD}} \\
(171-176)\end{array}$ & $\begin{array}{c}166 \pm 8^{\mathrm{AB}} \\
(163-168)\end{array}$ & $\begin{array}{c}165 \pm 9^{\mathrm{AB}} \\
(162-168)\end{array}$ & $<0.0001^{\mathrm{b}}$ \\
\hline $\mathrm{BMI}\left(\mathrm{kg} \mathrm{m}^{-2}\right)$ & $\begin{array}{c}25.6 \pm 3.0 \\
(24.7-26.6)\end{array}$ & $\begin{array}{c}25.4 \pm 2.8 \\
(24.5-26.2)\end{array}$ & $\begin{array}{c}24.9 \pm 3.0 \\
(24.0-25.8)\end{array}$ & $\begin{array}{c}24.4 \pm 3.1 \\
(23.4-25.4)\end{array}$ & $0.280^{\mathrm{b}}$ \\
\hline $\operatorname{ASA}(1 / 2 / 3)$ & $22 / 12 / 3$ & $11 / 25 / 4$ & $27 / 10 / 6$ & $13 / 21 / 4$ & $0.005^{c}$ \\
\hline Supramax (mA) & $\begin{array}{l}46 \pm 15 \\
(41-51)\end{array}$ & $\begin{array}{c}43 \pm 11 \\
(39-46)\end{array}$ & $\begin{array}{l}45 \pm 12 \\
(42-49)\end{array}$ & $\begin{array}{c}43 \pm 9 \\
(40-46)\end{array}$ & $0.455^{\mathrm{b}}$ \\
\hline
\end{tabular}

BMI = body mass index, ASA = American Society of Anesthesiologists' Physical Status Classification, Supramax = supramaximal current Data are mean $\pm \mathrm{SD}(95 \% \mathrm{CI})$, or frequencies.

${ }^{\mathrm{a}}$ Fisher's exact test, ${ }^{\mathrm{b}}$ One-way ANOVA with Tukey-Kramer multiple comparisons post-test, ${ }^{\mathrm{c}}$ chi-square test ${ }^{A} \mathrm{p}<0.05$ vs. young males, ${ }^{\mathrm{B}} \mathrm{p}<0.05$ vs. elderly males, ${ }^{\mathrm{C}} \mathrm{p}<0.05$ vs. young females, ${ }^{\mathrm{D}} \mathrm{p}<0.05$ vs. elderly females 
Table 2. Pharmacodynamics of rocuronium in young and elderly males and females.

\begin{tabular}{|c|c|c|c|c|c|}
\hline & \multicolumn{2}{|c|}{ Males (M) } & \multicolumn{2}{|c|}{ Females (F) } & \multirow{2}{*}{$P$-value } \\
\hline & $\begin{array}{c}\text { Young } \\
(20-40 \mathrm{yr})\end{array}$ & $\begin{array}{c}\text { Elderly } \\
(60-75 \mathrm{yr})\end{array}$ & $\begin{array}{c}\text { Young } \\
(20-40 \mathrm{yr})\end{array}$ & $\begin{array}{l}\text { Elderly } \\
(60-75 \mathrm{yr})\end{array}$ & \\
\hline Onset time (s) & $\begin{array}{c}90^{\mathrm{BCD}} \\
{[80-110]}\end{array}$ & $\begin{array}{c}135^{\mathrm{AC}} \\
{[116-165]}\end{array}$ & $\begin{array}{c}75^{\mathrm{ABD}} \\
{[60-90]}\end{array}$ & $\begin{array}{c}120^{\mathrm{AC}} \\
{[90-146]}\end{array}$ & $<0.001$ \\
\hline Clinical duration (min) & $\begin{array}{c}30^{\mathrm{BCD}} \\
{[25-42]}\end{array}$ & $\begin{array}{c}58^{\mathrm{AD}} \\
{[53-67]}\end{array}$ & $\begin{array}{c}50^{\mathrm{AD}} \\
{[40-65]}\end{array}$ & $\begin{array}{c}85^{\mathrm{ABC}} \\
{[70-90]}\end{array}$ & $<0.001$ \\
\hline Full recovery $(\min )$ & $\begin{array}{c}59^{\mathrm{BCD}} \\
{[51-67]}\end{array}$ & $\begin{array}{c}102^{\mathrm{A}} \\
{[75-106]}\end{array}$ & $\begin{array}{c}76^{\mathrm{AD}} \\
{[66-91]}\end{array}$ & $\begin{array}{c}128^{\mathrm{AC}} \\
{[94-137]}\end{array}$ & $<0.001$ \\
\hline
\end{tabular}

Data are median [interquartile range].

${ }^{a}$ non-parametric ANOVA (Kruskal-Wallis test) with multiple comparisons post-test (Dunn)

${ }^{A} p<0.05$ vs. young males, ${ }^{B} p<0.05$ vs. elderly males, ${ }^{C} p<0.05$ vs. young females, ${ }^{D} p<0.05$ vs. elderly females

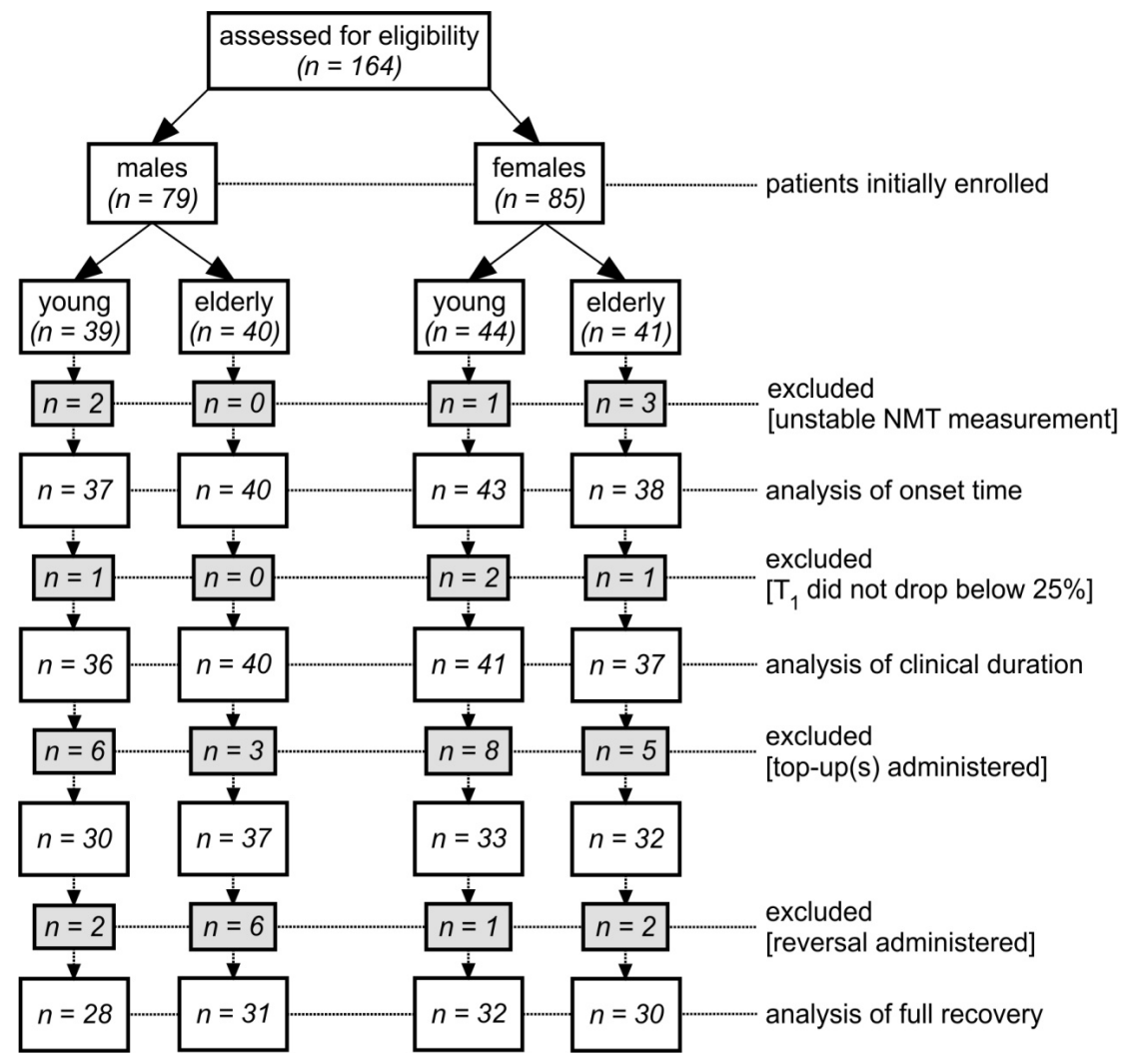

Fig. 1. Flow diagram illustrating the progress of patients through the clinical trial. Reasons for exclusion from the study are given in brackets. Young $=$ age 20-40 yrs, Elderly $=60-75 \mathrm{yrs}$

pulse in TOF-stimulation $\left(\mathrm{T}_{1}\right)$ was used to determine the onset time and clinical duration. These NMB parameters ${ }^{12}$ were measured in all patients:

- onset time (seconds) = time interval from the completion of the intravenous injection of rocuronium to maximal $\mathrm{T}_{1}$ depression

- clinical duration (minutes) = time interval from the completion of the intravenous injection of rocuronium to spontaneous recovery of $\mathrm{T}_{1}$ to $25 \%$ of the control value
- full recovery (minutes) = interval from the completion of the intravenous injection of rocuronium to spontaneous recovery to TOF-ratio 0.90 , which reflects complete recovery from the block

Data were recorded and transferred into Excel spreadsheet application (Microsoft Office 2007 SP2, Microsoft Corporation) for further analysis. 


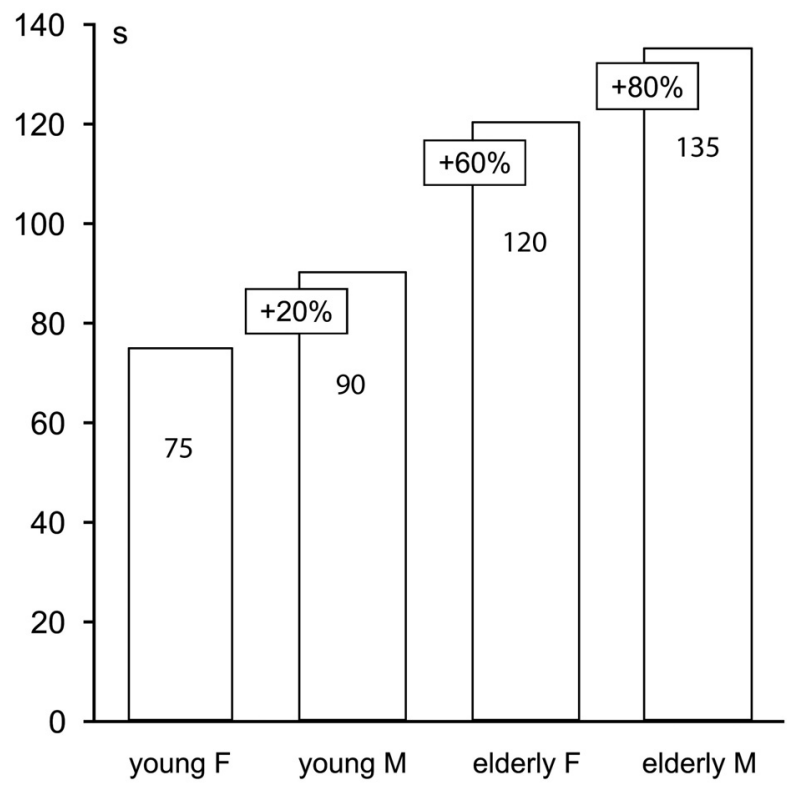

Fig. 2. Onset time in seconds (= time interval from the completion of the intravenous injection of rocuronium to maximal $\mathrm{T}_{1}$ depression in $\mathrm{TOF}$ stimulation).

Data are medians. The percentage values describe the increase compared to young females.

$\mathrm{M}=$ males, $\mathrm{F}=$ females, Young $=$ age $20-40 \mathrm{yrs}$, Elderly $=60-75 \mathrm{yrs}$

\section{Statistical analysis}

For calculations, we used the statistical software package InStat v. 3.10 (GraphPad Software, San Diego, California, U.S.A.). Comparisons between the groups were made using a one-way ANOVA with multiple comparisons post-test (Tukey-Kramer), non-parametric ANOVA (Kruskal-Wallis test) with multiple comparisons post-test (Dunn), chi-square, or Fisher's exact test, as appropriate. The results are expressed as means \pm SD (95\% CI) or medians [interquartile range (IQR)], or frequencies; $P$-values less than 0.05 were considered statistically significant.

\section{RESULTS}

The patients' demographics are summarized in Table 1. Males were significantly taller $(P<0.0001)$ and heavier $(P<0.0001)$ than females but the body mass index was comparable in both sexes. The older patients (both males and females) were assigned higher ASA classification.

164 patients ( 79 males, 85 females) were initially enrolled in the study. Fig. 1 shows the flow diagram illustrating the progress of patients through the clinical trial. Six patients were excluded because of unstable neuromuscular monitoring. In four patients, the $\mathrm{T}_{1}$ did not fall below $25 \%$, so the clinical duration was not determined. During surgery, the initial dose of rocuronium had to be supple-

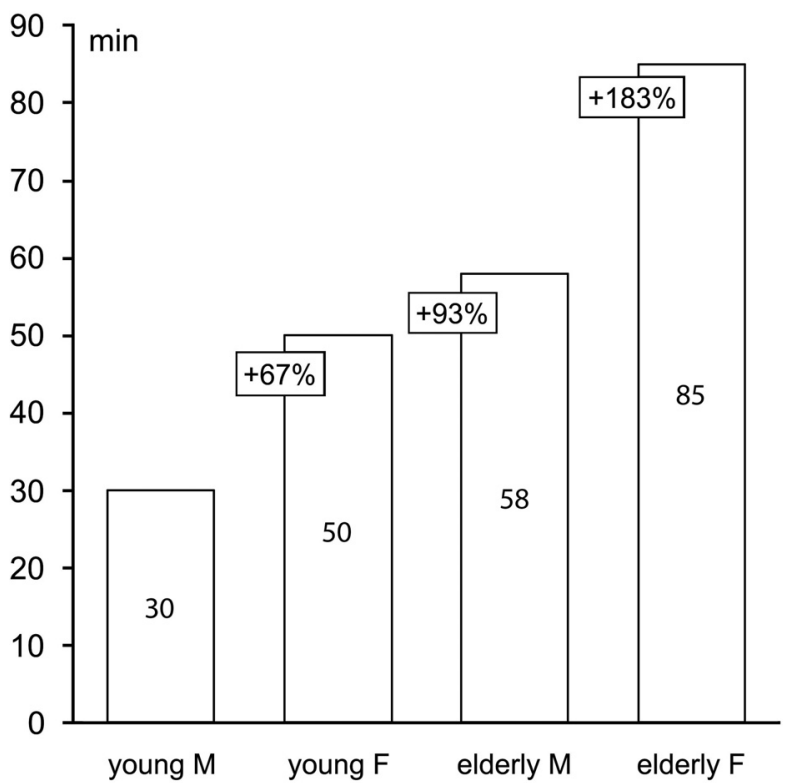

Fig. 3. Clinical duration in minutes (= time interval from the completion of the intravenous injection of rocuronium to spontaneous recovery of $\mathrm{T}_{1}$ to $25 \%$ of the control value in TOF-stimulation).

Data are medians. The percentage values describe the increase compared to young males.

$\mathrm{M}=$ males, $\mathrm{F}=$ females, Young $=$ age $20-40 \mathrm{yrs}$, Elderly $=60-75$ yrs

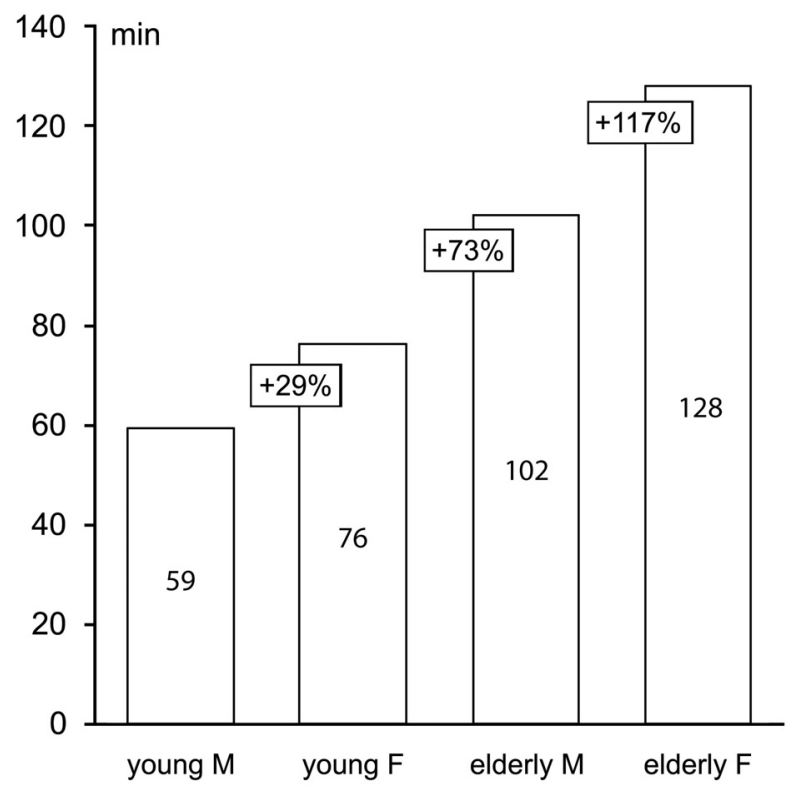

Fig. 4. Interval to full recovery in minutes (= interval from the completion of the intravenous injection of rocuronium to spontaneous recovery to TOFratio 0.90 , which reflects complete recovery from the block).

Data are medians. The percentage values describe the increase compared to young males.

$\mathrm{M}=$ males, $\mathrm{F}=$ females, Young $=$ age $20-40 \mathrm{yrs}$, Elderly $=60-75$ yrs 
mented with one or several top-ups in 22 cases. In 11 patients, reversal was necessary due to a residual block at the end of surgery. The resulting number of patients in whom the interval to full spontaneous recovery was obtained was 121 .

The PD data are listed in Table 2. The shortest onset time was in young females (median 75, IQR 60-90 s), the clinical duration was shortest in young males (median 30 , IQR 25-42 min), and finally, the interval to full recovery was shortest in young males (median 59, IQR 51-67 min). Fig. 2-4 show a percentage prolongation of these values in the other respective groups.

\section{DISCUSSION}

Our study confirmed a significant variability in the above parameters for the two genders and age groups of patients in response to $0.6 \mathrm{mg} \mathrm{kg}^{-1}$ rocuronium.

The onset times were shorter in females and were prolonged with aging in both genders. To make a NMB, rocuronium has to reach the neuromuscular junction. Lower cardiac output, prolonged circulation time, and decreased muscle blood flow with slower biophase equilibration may participate in the slower onset time in the elderly ${ }^{13}$. The clinical duration was significantly longer in females. Moreover, aging was associated with further prolongation of clinical duration in both males and females. Finally, full spontaneous recovery until TOF-ratio 0.9 was longer in females and it was further delayed in elderly patients of both genders. The highest differences were in the parameters describing the length of rocuronium effect (clinical duration and interval to full recovery). For example, in elderly females, the clinical duration was nearly three times longer than in young males.

Not only were differences in gender and age demonstrated in this study. There was a significant spread of PD parameters within respective groups (see Tab. 2). For example, in elderly females, the median clinical duration was 85 min with lower and upper quartiles 70 and $90 \mathrm{~min}$. This signifies that in only $50 \%$ of these cases, the clinical duration was in the range 70 to $90 \mathrm{~min}$.

This inevitably has important clinical implications. Residual block is one of the most dangerous adverse effects of incorrect use of NMBA. Based on the clinical signs, the assessment of postoperative residual curarization (PORC) is not reliable and hence even significant degrees of residual paralysis are not detected ${ }^{14}$. Due to a large variability in the effect of NMBA (rocuronium inclusive), the duration cannot precisely be predicted ${ }^{15}$. A long interval from the administration of an intermediate NMBA does not guarantee adequate recovery ${ }^{16}$. Without NMB monitoring, the anesthesiologist cannot be sure about the exact muscle strength at the end of anesthe$\operatorname{sia}^{17-19}$. Residual block not only reduces the coordination of pharyngeal muscles but also decreases the sensitivity of carotid chemoreceptors. Consequently, the patient with even small degrees of PORC cannot respond to hypoxia by increasing ventilation ${ }^{20}$. This may increase the risk of postoperative pulmonary complications ${ }^{21}$.
Today, rocuronium is one of the most often used nondepolarizing neuromuscular blockers worldwide. It is a very potent drug and if incorrectly used, it increases morbidity in surgical patients ${ }^{22,23}$. One can only speculate that its high popularity is further enhanced by the introduction of sugammadex into clinical practice. Sugammadex as a selective relaxant-binding agent has the ability to reverse the neuromuscular blockade induced by rocuronium and vecuronium $^{24,25}$. From the pharmacological point of view, sugammadex definitely has many advantages over the older reversal drugs such as neostigmine ${ }^{2,26-28}$. However, compared to neostigmine, it is much more expensive ${ }^{29}$. All these facts constitute a rationale for a thorough knowledge of the PD of rocuronium and its correct use.

\section{Gender}

There is increasing evidence for gender differences in the pharmacokinetics (PK) and PD of anesthetic drugs and NMBA (ref. ${ }^{30,31}$ ). Females have 20-30 \% greater sensitivity to the effects of aminosteroidal muscle relaxants ${ }^{4,5}$. This is probably due to different PK of aminosteroidal NMBA. In females, there is higher percentage of body fat, lower percentage of muscle mass and lower percentage of water and hence smaller distribution volume of rocuronium. In addition, the degradation and elimination of rocuronium are influenced by gender. Liver microsomal enzymes have different activity in males and females. In females, the glomerular filtration and renal clearance are lower so the elimination of rocuronium is decreased. In contrast, benzylisocholines undergo Hofmann elimination (a chemical process dependent on $\mathrm{pH}$ and temperature). Thus, tight physiological control of $\mathrm{pH}$ and temperature results in little variability in this biodegradation pathway without significant gender differences ${ }^{5,32}$.

\section{Aging}

Aging is accompanied by many physiological and pathophysiological changes that affect, like gender, the PK of various drugs ${ }^{7,8}$. The elderly are more often severely ill and may suffer from other diseases (co-morbidity). Their physical status, described by ASA, is generally worse than that of young patients. Elderly people often use drugs, which, although they control the concomitant diseases well (e.g. hypertension, ischemic heart disease or diabetes mellitus), can be a source of significant interactions. When prescribing drugs for seniors, polypragmasia is very common. For this reason, the risk of drug interactions is further increased with potential iatrogenic injury to the patient.

With aging, the structure and composition of body tissues change together with impaired organ functions, especially liver and kidney. However, the extent and onset of these changes is highly variable and rather than calendar age, the biological age is more important. Decrease in the total body water leads to lower central compartment and so a higher plasma concentration is usually reached following a single bolus dose of ROC. The lean body weight is lower. A higher content of fat tissue may potentially increase the clinical duration and interval to full recovery from rocuronium-induced blockade in the elderly. 
There are numerous changes in the neuromuscular junction with advancing age (e.g. decrease in the number of motor units, decreased number of preterminal axons, proliferation of extrajunctional receptors, decreased amount of acetylcholine in each motor neuron, or decreased amount of acetylcholine released in response to stimulation) ( ref. $^{33}$ ). However, the differences between young and elderly in the PD of ROC are not probably conditioned by the changes in the neuromuscular junction. The $\mathrm{ED}_{95}$ of ROC is similar in elderly $\left(0.4 \mathrm{mg} \mathrm{kg}^{-1}\right)$ and young $\left(0.5 \mathrm{mg} \mathrm{kg}^{-1}\right)$ patients ${ }^{34}$. When the elderly have the same plasmatic concentration of neuromuscular blocker as do young adults, they also have the same degree of neuromuscular block. Differences in PD, therefore, are probably due to differences in PK of the ROC in the elderly population ${ }^{35}$.

In summary, with aging, the essential factors involved in different reactivity to NMBA are reduced protein binding, changes in the composition of body tissues (muscle/ fat/water), drug metabolism and elimination (renal, liver), and finally, PD parameters ${ }^{7,8,37}$.

Our study has limitations. As we used a firm study protocol, there were significant dropouts (see Fig. 1). The data were collected during routine operations and under no circumstance did the protocol of the study alter the maintenance of anesthesia. The main source of dropouts (20\%) was the requirement for supplemental top-up(s) during surgery or the need for reversal at the end of anesthesia.

When assigning patients to groups according to age (20-40, or 60-75 years), we omitted the range of 41-59 years ${ }^{7}$. The reason for this was to separate sufficiently the two age groups studied. From a methodological point of view, the standard classification (e.g. to a younger group of 20-65 years and those aged more than 65 years) is not entirely correct. With this kind of thinking, a 65-year old patient would be qualified as "young" while a 66-year old would belong to "seniors". In this example, the clinical significance of the difference of one year is minimal, but for classifying into a particular group, it is crucial. This imperfection could be addressed by fuzzy logic but our approach to the division, creating a large enough "window" (41-59 years), we consider clinically correct.

For logistic reasons, we chose a non-interventional and non-blinded trial design. However, only the main author (MA) was responsible for the anesthetic management of all cases and a standardized technique was used for neuromuscular monitoring throughout the study. In all patients, the depth of anesthesia was computer-controlled (TCI) with identical target levels of respective anesthetic agents (propofol and sufentanil). TIVA was preferred to inhalation anesthesia to eliminate the influence of a volatile agent on the depth of muscle relaxation. We studied relatively healthy patients, mostly ASA 1 or 2 . From this point of view, our results cannot be automatically transferred to other types of anesthesia (volatile anesthetic) and/or different patients.

\section{CONCLUSION}

The effect of ROC is significantly influenced by both gender and age. In females, the onset time is shorter and clinical duration and full spontaneous recovery from rocuronium-induced block is longer than in males. These differences are further accentuated with aging and in addition, significant inter-individual variability of the effect of ROC exists. As the clinical examination cannot determine the degree of NMB exactly, these facts constitute evidence that neuromuscular monitoring is essential for safe use of rocuronium in surgical patients.

\section{ACKNOWLEDGEMENTS}

The authors gratefully acknowledge financial support from the Czech Ministry of Health Internal Grant Agency project No. NS 9618-4/2008.

Conflict of interest: Dr. Adamus is a member of the Advisory board of MSD (Schering-Plough, s.r.o., a subsidiary of Merck \& Co., Inc.) However, no support from MSD was received for this study.

Preliminary results were presented at meeting Euroanaesthesia 2011, Amsterdam, the Netherlands, June 11-14, 2011 (ref. ${ }^{37}$ ).

\section{REFERENCES}

1. Herold I. Muscle relaxants in anesthesiology and intensive care medicine [in Czech]. $1^{\text {st }}$ ed. Prague: Maxdorf; 2004.

2. Lee CL, Katz RL. Clinical implications of new neuromuscular concepts and agents: So long, neostigmine! So long, sux! J Crit Care 2009;24:43-9.

3. Lee C. Goodbye Suxamethonium! Anaesthesia 2009;64(Suppl 1):73-81.

4. Mencke T, Soltesz S, Grundmann U, Bauer M, Schlaich N, Larsen R, Fuchs-Buder T. Time course of neuromuscular blockade after rocuronium. A comparison between women and men. Anaesthesist 2000;49:609-12.

5. Adamus M, Gabrhelik T, Marek O. Influence of gender on the course of neuromuscular block following a single bolus dose of cisatracurium or rocuronium. Eur J Anaesthesiol 2008;25:589-95.

6. Arain S, Kern S, Ficke D, Ebert T. Variability of duration of action of neuromuscular blocking drugs in elderly patients. Acta Anaesthesiol Scand 2005;49:312-5.

7. Adamus M. Influence of age on the pharmacodynamic parameters of cisatracurium, rocuronium and vecuronium in males during total intravenous anaesthesia - A prospective study. [Article in Czech with English abstract]. Anest intenziv Med 2010;21:78-84.

8. Booij LHDJ, Drobnik L. Variability in the effect of muscle relaxants. Factors involved in the pharmacodynamic profile of neuromuscular blocking agents. Part II. Anestezjologia i Ratownictwo 2009;3:154-84.

9. Cazalaa JB, Levron JC, Servin F. Anesthetic agents used in TCI. Bibliographical study of anesthetic agents used in the Orchestra ${ }^{\circledR}$ Base Primea and Injectomat ${ }^{\circledR}$ TIVA Agilia. $2^{\text {nd }}$ ed. Le Grand Chemin, Brezins (France): Fresenius Vial, 2009.

10. Schnider TW, Minto CF, Shafer SL, Gambus PL, Andresen C, Goodale DB, Youngs EJ. The influence of age on propofol pharmacodynamics. Anesthesiology 1999;90:1502-16.

11. Gepts E, Shafer SL, Camu F, Stanski DR, Woestenborghs R, Van Peer A, Heykants JJ. Linearity of pharmacokinetics and model estimation of sufentanil. Anesthesiology 1995;83:1194-204. 
12. Fuchs-Buder T, Claudius C, Skovgaard LT, Eriksson LI, Mirakhur RK, Viby-Mogensen J. Good clinical research practice in pharmacodynamic studies of neuromuscular blocking agents II: the Stockholm revision. Acta Anaesthesiol Scand 2007;51:789-808.

13. Donati F. Onset of action of relaxants. Can J Anaesth 1988;35:S528.

14. Naguib M, Kopman AF, Ensor JE. Neuromuscular monitoring and postoperative residual curarisation: a meta-analysis. Br J Anaesth 2007:98:302-16.

15. Adamus M, Bělohlávek R, Vujčíková M, Janásková E. The impact of different rocuronium doses on its pharmacodynamic profile: A prospective study. [Article in Czech with English abstract]. Anest intenziv Med 2004;15:269-75.

16. Debaene B, Plaud B, Dilly MP, Donati F. Residual paralysis in the PACU after a single intubating dose of nondepolarizing muscle relaxant with an intermediate duration of action. Anesthesiology 2003;98:1042-8.

17. Murphy GS, Brull SJ. Residual neuromuscular block: lessons unlearned. Part I: definitions, incidence, and adverse physiologic effects of residual neuromuscular block. Anesth Analg 2010;111:120-8.

18. Viby-Mogensen J, Claudius C. Evidence-based management of neuromuscular block. Anesth Analg 2010;111:1-2.

19. Donati F. Neuromuscular monitoring: what evidence do we need to be convinced? Anesth Analg 2010;111:6-8.

20. Eriksson LI, Sundman E, Olsson R, Nilsson L, Witt H, Ekbery O, Kuylenstierna R. Functional assessment of the pharynx at rest and during swallowing in partially paralyzed humans. Anesthesiology 1997;87:1035-43.

21. Berg H, Roed J, Viby-Mogensen J, Mortensen CR, Engbaek J, Skovgaard LT, Kristel JJ. Residual neuromuscular block is a risk factor for postoperative pulmonary complications. A prospective, randomised, and blinded study of postoperative pulmonary complications after atracurium, vecuronium and pancuronium. Acta Anaesthesiol Scand 1997;41:1095-103.

22. Murphy GS, Szokol JW, Marymont JH, Greenberg SB, Avram MJ, Vender JS. Residual neuromuscular blockade and critica respiratory events in the postanesthesia care unit. Anesth Analg 2008; 107:130-7.

23. Sauer M, Stahn A, Soltesz S, Noeldge-Schomburg G, Mencke T. The influence of residual neuromuscular block on the incidence of critical respiratory events. A randomised, prospective, placebo- controlled trial. Eur J Anaesthesiol 2011 [Epub ahead of print]. Doi: 10.1097/EJA.0b013e328345cd11.

24. Naguib M, Brull SJ. Sugammadex: a novel selective relaxant binding agent. Expert Rev Clin Pharmacol 2009;2:37-53.

25. Suy K, Morias K, Cammu G, Hans P, van Duijnhoven WG, Heeringa M, Demeyer I. Effective reversal of moderate rocuronium - or vecuronium-induced neuromuscular block with sugammadex, a selective relaxant binding agent. Anesthesiology 2007;106:283-8.

26. Kopman AF, Eikermann M. Antagonism of non-depolarising neuromuscular block: current practice. Anaesthesia 2009;64(Suppl 1):22-30.

27. Miller RD, Ward TA. Monitoring and pharmacologic reversal of a nondepolarizing neuromuscular blockade should be routine. Anesth Analg 2010;111:3-5.

28. Caldwell J E. Clinical limitations of acetylcholinesterase antagonists. J Crit Care 2009;24:21-8

29. Kopman AF. Neostigmine versus sugammadex: which, when, and how much? Anesthesiology 2010;113:1010-1.

30. Pleym H, Spigset O, Kharasch ED, Dale O. Gender differences in drug effects: implications for anesthesiologists. Acta Anaesthesiol Scand 2003:47:241-59.

31. Soldin OP, Mattison DR. Sex differences in pharmacokinetics and pharmacodynamics. Clin Pharmacokinet 2009;48:143-57.

32. Schmith VD, Fiedler-Kelly J, Phillips L, Grasela TH Jr. Prospective use of population pharmacokinetics/pharmacodynamics in the development of cisatracurium. Pharm Res 1997;14:91-7.

33. Naguib M, Lien AC. Pharmacology of Muscle Relaxants and Their Antagonists. In: Miller RD (editor). Miller's Anesthesia. $7^{\text {th }}$ ed. Philadelphia: Churchill-Livingstone, Elsevier; 2010, p. 897.

34. Bevan DR, Fiset P, Balendran P, Law-Min JC, Ratcliffe A, Donati F. Pharmacodynamic behaviour of rocuronium in the elderly. Can J Anaesth 1993:40:127-32.

35. Lien AC. Nondepolarizing Neuromuscular Blocking Agents in the Elderly: Dosing Paradigms Revisited. Book of Proceedings from the Congress: Perioperative Care for the Geriatric Patient. Prague, June 14-16, 2009

36. Sieber FE, Pauldine R. Geriatric Anesthesia. In: Miller RD (editor). Miller's Anesthesia. $7^{\text {th }}$ ed. Philadelphia: Churchill-Livingstone, Elsevier 2010, p. 2271

37. Adamus M, Konupcikova K, Wanek T, Hrabalek L. Influence of age and gender on the pharmacodynamic parameters of rocuronium during total intravenous anaesthesia. Eur J Anaesthesiol 2011;28(S48): 9AP2-4,131 
